\title{
The Feasibility of Microwave Ovens for Drying Plant Samples
}

\section{MEGEEN C. SMITH}

Abstract

Microwave ovens appear to be a viable alternative to forced air laboratory ovens for obtaining dry weights for vegetution samples. Two grass species, Kentucky bluegrass (Poa pratensis) and tall fescue (Festuca arundinacea), were used to determine percent moisture loss by weight at 3 weight loadings. The loadings were at approximately 50, 100, and 200 weights. For the 3 loadings, times required to obtain a dried sample were at most $4.5,7.5$, and 11.0 minutes, respectively. The time required for all samples in the conventional lab oven was 72 hours.

\section{Methods}

Two grass samples were clipped and placed in plastic bags for transport to the laboratory in early May, 1980. Poa pratensis and Festuca arundinacea were the 2 species chosen to study in the Corvallis, Ore., area.

Control samples were weighed and dried in paper bags for 48 hours. The samples were weighed again and dried for another 24 hours to include any added moisture losses.

The test samples were chopped in a standard kitchen blender (Hamilton Beach 14-speed) to resemble lawnmower clippings. The

\footnotetext{
Author was a senior rangeland resources student at Oregon State University at the time of research.

Unfunded research done as a student research project.
}

chopping was done to render more even moisture evacuation from tissues in the heavy culms of the grass plants. With a rapid drying process, charring may occur in spots while other areas are not dried at all due to trapped moisture. Chopping alleviates this problem.

The microwave oven drying treatments were done in a Litton Systems $70 / 42$ oven operating at full power. The $50-g$ samples were dried at 30-second intervals until they ceased further weight loss. The 100-g samples were treated and weighed at 1.0-minute intervals until the $50-\mathrm{g}$ samples time had elapsed. At this point the samples were dried and weighed at 30 -second intervals until the samples had no further weight loss. Minor charring occurred in 2 of the $100-\mathrm{g}$ samples. The $200-\mathrm{g}$ samples were treated similarly with 1.0-minute intervals until the $100-\mathrm{g}$ time had elapsed with 30 second intervals after that.

All microwave samples were dried in a Pyrex glass casserole dish.

\section{Results}

It was found in the microwave oven treatments, that increased weight loadings required a longer drying time. Table 1 shows the per cent moisture content of Poa pratensis at all 3 loadings with a comparison of times between the lab oven control samples and microwave oven test samples. From the table we see that various loading weights require different lengths of drying time in the microwave oven. Table 2 shows similar data for Festuca arnondinacea. 
Table 1. Time and weight loading chart for oven dried control and microwave oven dried teat with per cent molature content. (Poe pratensis) Kentucky bluegrass.

\begin{tabular}{lll}
\hline \hline & \multicolumn{2}{c}{ Per cent moisture content } \\
\cline { 2 - 3 } $\begin{array}{l}\text { Weight loadings } \\
\text { (approx.) }\end{array}$ & $\begin{array}{l}\text { Oven-dried } \\
\text { control }\end{array}$ & $\begin{array}{l}\text { Microwave oven-dried } \\
\text { test }\end{array}$ \\
\hline $50 \mathrm{~g}$ & $85.9^{*}$ & $82.4(4.0 \mathrm{~min})$. \\
$100 \mathrm{~g}$ & $85.1^{*}$ & $84.0(7.0 \mathrm{~min})$. \\
$200 \mathrm{~g}$ & $83.9^{*}$ & $83.6(11.0 \mathrm{~min})$. \\
& average $84.96 \%$ & $83.33 \%$ \\
\hline
\end{tabular}

Table 2. Time and weight loading chart for oven dried control and microwave oven dried teat whth per cent moisture content. (Festuca arundinacen) tall fescue.

\begin{tabular}{|c|c|c|}
\hline \multirow[b]{2}{*}{$\begin{array}{l}\text { Weight loadings } \\
\text { (approx.) }\end{array}$} & \multicolumn{2}{|c|}{ Per cent moisture content } \\
\hline & $\begin{array}{l}\text { Oven-dried } \\
\text { control }\end{array}$ & $\begin{array}{l}\text { Microwave oven-dried } \\
\text { test }\end{array}$ \\
\hline $\begin{array}{r}50 \mathrm{~g} \\
100 \mathrm{~g} \\
200 \mathrm{~g}\end{array}$ & $\begin{array}{l}82.4^{*} \\
84.4^{*} \\
84.5^{*} \\
83.77 \%\end{array}$ & $\begin{array}{l}82.0(4.5 \mathrm{~min} .) \\
81.2(7.5 \mathrm{~min}) \\
83.2(11.0 \mathrm{~min} .) \\
82.17 \%\end{array}$ \\
\hline
\end{tabular}

-...Samples dried for 72 hours (4320 minutes).

Figure 1 is a Moisture Loss by Weight Curve for Poa pratensis. The 51-g sample of Poa pratensis reached the conventional oven dry weight in 40 minutes, while the $100-\mathrm{g}$ and $200-\mathrm{g}$ samples required 7.0 and 11.0 minutes respectively to reach the same level of moisture withdrawal (Fig. 1).

In Figure 2 similar data appear for Festuca arundinacea. In the Moisture Loss by Weight Curve, the 50-gram sample required 4.5 minutes to reach conventional oven dry weight, while the $101-\mathrm{g}$ and 203-g samples required 7.5 and 11.0 minutes respectively.

\section{Conclusions}

The time efficiency for microwave oven drying is substantial. A comparison of 11.0 minutes and 72 hours ( 4320 minutes) may be very time and cost effective.

Lawnmower clippings collected in a catcher bag may prove to be usable without further chopping for pasture analysis.

In a small laboratory operation, a microwave oven could be a multiple purpose appliance for drying vegetative and soil samples.

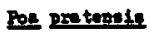

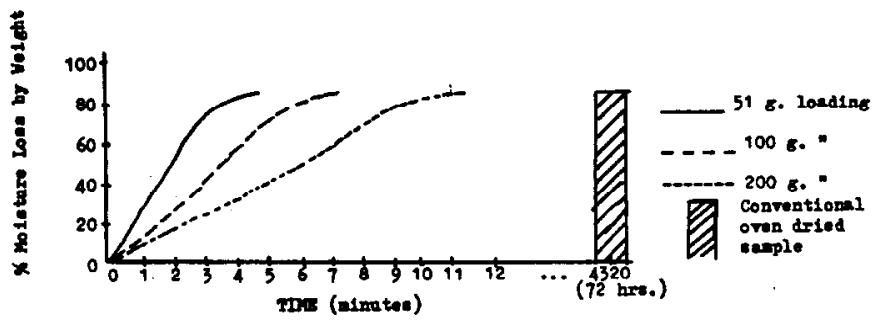

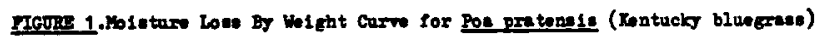

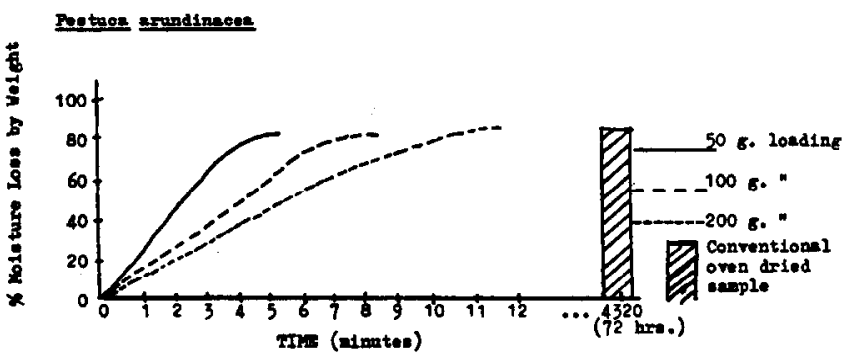

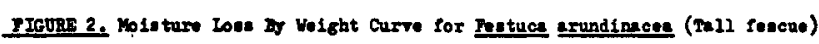

Microwave ovens are portable and may be stored when not in use if space is limited. They can also be put on rolling carts and moved from one lab to another if the need arises.

Microwave ovens may be purchased at appliance centers for $\$ 200.00$ to $\$ 800.00$. Laboratory ovens, like most lab equipment, are very expensive, with an estimated replacement cost of $\$ 7,000.00$ for the oven used in this study.

Microwave ovens run on standard 110 current, while large lab ovens require special wiring for greater currents. It would be possible to design a portable laboratory with a power plant for mobile field labs equipped with blender, microwave oven, scales, etc. With the availability of rapid results, same-day analysis could be a real bonus in range management practices.

It should be mentioned that the question of using this method for nutrient analysis and forage quality has not been answered yet. Care should also be taken when using this method for drying samples. Overdrying and charring can occur if samples are not carefully monitored. Fire is a risk, and as with all laboratory methods, caution is necessary. 